\title{
ОЦІНКА ВПЛИВУ ТЕМПЕРАТУРНИХ ПОКАЗНИКІВ НА ФОРМУВАННЯ МАЛЯРІОГЕННОСТІ ТЕРИТОРІЇ УКРАЇНИ
}

\author{
Національний університет «Києво-Могилянська академія»
}

\begin{abstract}
Малярія - антропонозна трансмісивна хвороба, частка якої становить 2,6 \% від усіх захворювань у світі. При оцінці рівня маляріогенності території враховують показники температури повітря. Зміна клімату може створити сприятливіші умови для поширення малярії; необхідною є оцінка просторового розподілу переносників і збудників малярії для подальшого визначення потенційних ареалів цих видів. Порівняно температурні показники (1991-2010 рр.) і прогнози (Шевченко, 2014) для 5 регіонів України (Північний, Південний, Східний, Західний, Центральний) з температурними діапазонами толерантності для переносників малярії (комарів Anopheles) та збудників (P. vivax, $P$. malariae, $P$. falciparum).

Сорормовані кліматичні особливості України перед-
\end{abstract} бачають придатні умови для завершення статевого розвитку малярійних плазмодіїв виду P. vivax ma P. malariae в організмі комара у всіх регіонах країни влітку. Для формування спорозоїтів P. falciparum необхідною є середньосезонна температура не нижче $18{ }^{\circ} \mathrm{C}$, що не спостерігається в наш час та не прогнозується в майбутньому у межах Західного регіону. Температури на території Україні взимку не є оптимальними для розвитку спорозоїтів в організмі комара, а тому можуть виступати лімітуючим фрактором при поширенні малярії.

Розповсюдження комарів Anopheles, залежно від сорормованих кліматичних умов і майбутніх змін, $\epsilon$ можливим по всій території України. Температурні оптимуми забезпечення життєдіяльності комарів Anopheles найбільш притаманні Південному регіону України, що сприяє створенню тут потенційних осередків з великою чисельністю переносників.

Наразі кліматичні характеристики Україні відповідають помірному ризику поширення малярії (відповідно до методичних вказівок МОЗ Російської Федераuіi). Температурні прогнози до 2030 р. обумовлюють можливе підвищення ризику до відносно високого, що підкреслює важливість нових адаптаційних заходів, пов'язаних із загрозою зміни клімату.

Ключові слова: малярія, малярійний плазмодій, переносник (комар роду Anopheles), зміна клімату.
Малярія - антропонозна трансмісивна протозойна хвороба, частка якої становить 2,6 \% від усіх захворювань у світі [1]. Враховуючи останні оцінки ВОО3, у 2015 р. кількість випадків зараження малярією становила 214 млн, а 438 тис. 3 них мали летальні наслідки [2].

Наразі Україна належить до країн неендемічного походження цих паразитів; за період 2011-2013 рр. виявлено 220 випадків завізної малярії, переважно 3 країн Африки та Центральної Азії [3]. Потенційно небезпечними переносниками малярії для території України $€ 4$ види комарів, зокрема: A. messeae, A. atroparvus, A. plumbeus та A. hyrcanus. Існування кожного $з$ цих видів обумовлюється певними температурними особливостями [4]. Ключовим збудником $€ P$. vivax, що має здатність поширюватися в помірні широти та в основному детермінує захворюваність малярією на території України та країн СНД [5].

Однією з ключових характеристик при оцінці маляріогенності території виступають температурні показники. Організми, що є переносниками трансмісивних хвороб, не спроможні підтримувати температуру тіла на стабільному рівні, а тому чутливі до температури навколишнього середовища.

За останні двадцять років (1991-2010рр.) середньорічна температура повітря на території України зросла на 0,8 ${ }^{\circ} \mathrm{C}$ [6]. Кліматичні прогнози передбачають подальше збільшення температури повітря: за даними О. Шевченко [7], до 2030 р. спостерігатиметься підвищення середньорічної температури повітря по Україні в межах $0,44{ }^{\circ} \mathrm{C}$.

Зміни клімату можуть суттєво вплинути на розподіл видів переносників малярії, створюючи більш сприятливі умови для їх розмноження; тому актуальним є вивчення змін просторового розподілу таких видів.

Метою дослідження є оцінка впливу температурних показників і трендів на просторовий розподіл і можливість розвитку переносників та збудників малярії людини в межах території України.

\section{Матеріали і методи}

Дані температури повітря, що беруться до уваги при оцінці можливості перебігу спорогонії на території України 


\section{ОРИГІНАЛЬНІ ДОСЛІДЖЕННЯ}

в зимовий та літній періоди, визначались за допомогою карт середніх зимових і літніх ізотерм на період 19912010 рр. [7]. Прогностична оцінка зміни середньої річної приземної температури в Україні базується на роботі О. Шевченко [7], де подана таблиця проекції змін середньомісячних температур по регіонах у 2011-2030 рр. відносно кліматичної норми (значень на період 1991-2010рр.).

Для оцінки можливості завершення повного статевого розвитку малярійними плазмодіями в організмі комара за основу були взяті температурні показники, що відрізняються залежно від виду збудника. Так, за дослідженнями Грассі (1900) встановлено, що мінімальна температура для розвитку $P$. malariae була $16,5^{\circ} \mathrm{C}$, для $P$. vivax $17,5^{\circ} \mathrm{C}$, a для P. falciparum $18{ }^{\circ} \mathrm{C}$ [8]. Тривалість процесу спорогонії $P$. vivax при різних температурах повітря визначалася за Огановим-Раєвським [9].

Класифікація ступеня маляріогенності території подана на основі методичних вказівок Міністерства охорони здоров'я РФ. У поданій класифрікації враховується кількість днів з температурами вище $15^{\circ} \mathrm{C}$. Тривалість даного періоду безпосередньо визначає ступінь маляріогенності території та ризик поширення малярії в певному регіоні [9].

Кількість днів з температурами вище $15^{\circ} \mathrm{C}$ було визначено з використанням даних А. Польового і співавт. [10], де зазначено природно-кліматичні райони України та тривалість періоду з температурами повітря вище $15^{\circ} \mathrm{C}$ на 1991-2005 рр. та до 2030 р. Результати дослідження подано для п'яти основних регіонів України: до Північного регіону віднесено територію Полісся; Західний регіон включає Прикарпаття та Закарпаття; Центральний - Лісостеп; у Східний регіон було включено Північний Степ; до Південного регіону віднесено Південний Степ і територію Криму.

\section{Результати досліджень та їх обговорення}

Як було зазначено, перебіг стадій спорогонії, які відбуваються в організмі комара, визначається температурою оточуючого середовища; мінімальною температурою для розвитку P. malariae $€ 16,5^{\circ} \mathrm{C}$, для $P$. vivax - $17,5^{\circ} \mathrm{C}$, а для P. falciparum - $18^{\circ} \mathrm{C}$ [8]. Разом 3 тим, середня за зиму приземна температура повітря в Україні коливається в межах від $-4^{\circ} \mathrm{C}$ на Північному Сході до $+1{ }^{\circ} \mathrm{C}$ в Криму [7] і кліматичні прогнози на період до 2030 р. передбачають підвищення температури в середньому на $0,44{ }^{\circ} \mathrm{C}$. Такі температурні показники не відповідають оптимальним умовам утворення спорозоїтів в організмі комара, а навпаки, виступають лімітуючими факторами (табл. 1). Це, у свою чергу, робить неможливим поширення інорекції в зимовий період по території України.

Таблиця 1

Можливість завершення спорогонії в зимовий період, за регіонами України

\begin{tabular}{|c|c|c|c|c|c|}
\hline \multirow{2}{*}{$\begin{array}{l}\text { Регіон } \\
\text { України }\end{array}$} & \multirow{2}{*}{$\begin{array}{l}\text { Температура повітря, } \\
\text { 1991-2010 рр., }{ }^{\circ} \mathrm{C}\end{array}$} & \multirow{2}{*}{$\begin{array}{c}\text { Проекція змін температури, } \\
\text { до } 2030 \text { р., }{ }^{\circ} \mathrm{C}\end{array}$} & \multicolumn{3}{|c|}{ Можливість завершення спорогонії } \\
\hline & & & P. malariae & P. vivax & P. falciparum \\
\hline Північ & -3 & 0,45 & відсутня & відсутня & відсутня \\
\hline Захід & -2 & 0,41 & відсутня & відсутня & відсутня \\
\hline Центр & -3 & 0,44 & відсутня & відсутня & відсутня \\
\hline Схід & -4 & 0,5 & відсутня & відсутня & відсутня \\
\hline Південь & +1 & 0,43 & відсутня & відсутня & відсутня \\
\hline
\end{tabular}

Влітку середня за сезон приземна температура повітря коливається в межах від $+17^{\circ} \mathrm{C}$ на Заході до $+22^{\circ} \mathrm{C}$ на Півдні та в Криму [7]. Таким чином, на території України створюються умови, що є придатними для завершення повного статевого розвитку малярійного плазмодія в організмі комара, окрім Західного регіону для P. falciparum (табл. 2). Тож, фрормування маляріогенності території України безпосередньо залежить від територіального розподілу та меж коливання температури повітря у теплий період року.

Таблиця 2

Можливість завершення спорогонії в літній період, за регіонами України

\begin{tabular}{|l|c|c|l|l|l|}
\hline \multirow{2}{*}{$\begin{array}{c}\text { Регіон } \\
\text { України }\end{array}$} & \multirow{2}{*}{$\begin{array}{c}\text { Температура повітря, } \\
1991-2010 \text { рр., }{ }^{\circ} \mathrm{C}\end{array}$} & $\begin{array}{c}\text { Проекція змін температури, } \\
\text { до } 2030 \text { р., }{ }^{\circ} \mathrm{C}\end{array}$ & \multicolumn{2}{c|}{ Можливість завершення спорогонії } \\
\cline { 4 - 6 } & +18 & 0,45 & наявна & наявна & наявна \\
\hline Північ & +17 & 0,41 & наявна & наявна & відсутня \\
\hline Захід & +18 & 0,44 & наявна & наявна & наявна \\
\hline Схір & +20 & 0,5 & наявна & наявна & наявна \\
\hline Південь & +22 & 0,43 & наявна & наявна & наявна \\
\hline
\end{tabular}


При аналізі кліматичних особливостей, що забезпечують розвиток та підтримку життєдіяльності імаго комарів роду Anopheles, було встановлено, що для багатьох видів пік активної життєдіяльності забезпечується за температур, що коливаються в межах 25-30 $\mathrm{C}$ [11]. Так, на території України близькими до оптимальних $\epsilon$ умови, що сорормувалися на Півдні та в Криму. Температура влітку тут сягає близько $22^{\circ} \mathrm{C}$, а враховуючи майбутні зміни показників у цих регіонах до 2030 р., в середньому на $0,43{ }^{\circ} \mathrm{C}$, вони забезпечать повноцінне існування дорослих особин комарів роду Anopheles.

Базуючись на середніх значеннях сезонних температур повітря, що є провідними при визначенні ризику розповсюдження малярії, було проаналізовано регіони України та визначено особливості поширення хвороби на території кожного з них (табл. 3).

Таблиця 3

Особливості поширення малярії в Україні за сфрормованих кліматичних показників

\begin{tabular}{|c|c|c|c|c|c|}
\hline $\begin{array}{l}\text { Регіон } \\
\text { України }\end{array}$ & $\begin{array}{c}\text { Температура } \\
\text { повітря, 1991- } \\
2010 \text { рр., }{ }^{\circ} \mathrm{C}\end{array}$ & $\begin{array}{l}\text { Тривалість } \\
\text { спорогонії } \\
\text { P. vivax, дні }\end{array}$ & $\begin{array}{c}\text { Потенційний } \\
\text { переносник }\end{array}$ & $\begin{array}{c}\text { Кількість днів з темпе- } \\
\text { ратурами повітря } \\
\text { вище } 15^{\circ} \mathrm{C}[10]\end{array}$ & $\begin{array}{c}\text { Ступінь маляріогенності } \\
\text { території [9] }\end{array}$ \\
\hline Північ & +18 & 29 & \multirow{5}{*}{$\begin{array}{l}\text { A. messeae, } \\
\text { A. atroparvus, } \\
\text { A. plumbeus, } \\
\text { A. hyrcanus }\end{array}$} & $103-107$ & помірного ризику \\
\hline Захід & +17 & 38,5 & & $108-136$ & помірного та стійкого ризику \\
\hline Центр & +18 & 29 & & $110-115$ & помірного ризику \\
\hline Схід & +20 & 19 & & $123-126$ & стійкого ризику \\
\hline Південь & +22 & 15 & & $134-138$ & стійкого ризику \\
\hline
\end{tabular}

Як зазначено в таблиці 3, наразі на території України існує помірний та стійкий ризик поширення малярії. Це пояснюється відносно тривалим періодом з температурами повітря вище $15^{\circ} \mathrm{C}$, що сприяє завершенню більшої кількості циклів спорогонії малярійними плазмодіями в організмі комара. Тривалість статевого розмноження $P$. vivax в організмі комара безпосередньо залежить від температурних показників і $€$ найменшою на Півдні України (15 діб). Це становить підвищену небезпеку для регіону з огляду на можливість збільшення відсотка заражених комарів та відповідно вищий рівень захворюваності малярією.

Нами було створено прогнозовану картину поширення малярії в Україні на період до 2030 р. з врахуванням потенційних змін середньорічних температурних показників на території країни (табл. 4).

Таблиця 4

Прогнозовані зміни поширення малярії по території України

\begin{tabular}{|c|c|c|c|c|c|}
\hline $\begin{array}{l}\text { Регіон } \\
\text { України }\end{array}$ & $\begin{array}{c}\text { Температура } \\
\text { повітря, }{ }^{\circ} \mathrm{C}\end{array}$ & $\begin{array}{l}\text { Тривалість } \\
\text { спорогонії } \\
\text { P. vivax, дні }\end{array}$ & $\begin{array}{c}\text { Потенційний } \\
\text { переносник }\end{array}$ & $\begin{array}{c}\text { Кількість днів з темпе- } \\
\text { ратурами повітря } \\
\text { вище } 15^{\circ} \mathrm{C}[10]\end{array}$ & $\begin{array}{c}\text { Ступінь маляріогенності } \\
\text { території [9] }\end{array}$ \\
\hline Північ & $+18,5$ & 26 & \multirow{5}{*}{$\begin{array}{l}\text { A. messeae, } \\
\text { A. atroparvus, } \\
\text { A. plumbeus, } \\
\text { A. hyrcanus }\end{array}$} & $163-167$ & високого ризику \\
\hline Захід & $+17,4$ & 32 & & 160-193 & високого ризику \\
\hline Центр & $+18,4$ & 26 & & $157-170$ & високого ризику \\
\hline Схід & $+20,5$ & 18 & & $174-180$ & високого ризику \\
\hline Південь & $+22,4$ & 13 & & $183-189$ & високого ризику \\
\hline
\end{tabular}

Як видно з даних таблиці 4, найбільш сприятливим регіоном для існування нових вогнищ малярії $€$ Південь України. Тривалість спорогонії $P$. vivax скоротиться тут з 15 до 13 діб, що вплине на підвищення кількості пророблених циклів за епідсезон, збільшення частки інфікованих комарів та підвищення інтенсивності передачі малярії. Кількість днів з температурами повітря вище $15{ }^{\circ} \mathrm{C}$ тут найбільша - від 183 до 189 діб. Це свідчить про відносно тривалий епідемічний сезон, що буде формувати зону з високим ризиком поширення малярії.

Отже, проведений аналіз можливості поширення малярії в Україні з врахуванням впливу кліматичних факторів на просторовий розподіл і забезпечення розвитку переносників і збудників інсекційного захворювання показує, що на території України наразі існує помірний та стійкий ризик поширення малярії, обумовлений наявністю оптимальних умов абіотичного середовища для ії передачі. Прогнозовані зміни на період до 2030 р. сприятимуть виникненню нових вогнищ і відносно високого ризику розповсюдження малярії.

\section{Висновки}

1. Сорормовані кліматичні особливості України та майбутні зміни температурних показників передбачають придатні умови для завершення повного статевого роз- 
витку малярійними плазмодіями виду P. vivax та P. malariae в організмі комара у всіх регіонах країни влітку. Для фрормування спорозоїтів $P$. falciparum необхідною є середньосезонна температура не нижче $18^{\circ} \mathrm{C}$, що не спостерігається в наш час та не прогнозується в майбутньому у межах Західного регіону.

2. Розповсюдження комарів роду Anopheles, залежно від сорормованих кліматичних умов і майбутніх змін, $€$ можливим по всій території України. Однак їх поширення визначається в першу чергу температурними оптимумами, що є більш сприятливими на Півдні України, а тому потенційно формують тут осередки з великою чисельністю переносників.

Ключовим фрактором при фрормуванні маляріогенності території України виступають температурні показники, що наразі сприяють утворенню помірного та стійкого ризику поширення малярії, а їх прогнозовані зміни обумовлюють виникнення відносно високого ризику передачі захворювання у період до 2030 р. Таким чином, у випадку появи інфрікованих малярійними плазмодіями людей підвищиться ймовірність виникнення джерела інорекції, а наявність комарів роду Anopheles може забезпечити передачу збудника та сприяти формуванню місцевих осередків хвороби.

\section{Література}

1. Єршова, І., Осипова, Т., Мочалова, Г., Калапала Б. (2014) Малярія. Актуальна інфектологія, 2(3), 50-62.

2. World malaria report 2015. (2015). Geneva: World Health Organization.

3. Державна санітарно-епідеміологічна служба України. (2014). 25 квітня Всесвітній день боротьби проти малярії. Режим доступу http://www.dsesu.gov.ua/ua/dses-ua/novyny/item/589-25kvitnia-vsesvitnii-den-borotby-proty-maliarii

4. Практическое руководство по элиминации малярии. (2010). Всемирная организация здравоохранения.

5. Лысенко, А., Семашко, И. (1968). Geography of malaria. Moscow: Geography.

6. Барабаш, М., Татарчук, О., Гребенюк, Н., Корж, Т. (2009). Практичний напрямок досліджень зміни клімату в Україні. Фізична географрія та геоморфологія, 57, 28-35.

7. Шевченко, О. (2014). Оцінка вразливості до зміни клімату. Кліматичний форум східного партнерства та Робоча група громадських організацій зі зміни клімату.

8. Manguin, S., Carnevale, P., \& Mouchet, J. (2008). Biodiversity of malaria in the world. Paris: John Libbey Eurotext.

9. Профилактика паразитарных заболеваний. Малярийные комары и борьба с ними на территории Российской Федерации. (2000). Методические указания МУ 3.2.974-00. - утв. Главным государственным санитарным врачом, Первым заместителем Министра здравоохранения Российской Федерации. Режим доступа http://www.lawrussia.ru/texts/legal 222/doc222a395x941.htm

10. Польовий, А., Божко, Л., Дронова, О. (2011). Аналіз тенденції змін термічних показників агрокліматичних ресурсів в Україні за період до 2030-2040рр. Український гідрометеорологічний журнал, 9, 90-99.

11. Malaria Vectors and Approaches to their Control. (2001). Kazakhstan: World Health Organization.

\section{EVALUATION OF TEMPERATURE CHARACTERISTICS IMPACT ON THE FORMATION OF THE MALARIOGENIC SITUATION IN UKRAINE}

\section{O. Zabarna, O. Khalaim}

National University of Kyiv-Mohyla Academy

SUMMARY. Malaria is an anthroponotic protozoan vector-borne disease which takes $2.6 \%$ of all worldwide diseases. To estimate the level of malariogenic potential of a certain territory, air temperature data should be taken into account. Due to shifting the temperature patterns, climate change can create more appropriate conditions for malaria spreading; that is why it is important to estimate spacial distribution of malaria vectors and parasites for further evaluation of these species' areal increase. In this research we have compared the temperature data (1991-2010) and prognoses (Shevchenko, 2014) for 5 main regions of Ukraine (Northern, Southern, Eastern, Western, and Central) with a temperature range tolerance for malaria vector (mosquito g. Anopheles) and parasites (P. vivax, $P$. malariae and $P$. falciparum).

Climatic conditions in Ukraine allow executing a full sporogonic cycle of P. vivax and P. malariae in mosquito organism in all regions during the summer period. To form sporozoites $P$. falciparum the average seasonal temperature should not be lower than $18^{\circ} \mathrm{C}$, which is not expected for Western part of Ukraine. Winter temperatures in Ukraine are not optimal for sporozoites development in the organism of a mosquito and can be regarded as limiting factors for malaria spread in winter. At the same time, spreading of mosquito g. Anopheles is possible on the territory of Ukraine according the current climatic situation and prognosis made. The optimal air temperatures for mosquito g. Anopheles lifecycle can be found at Southern Ukraine which determines a high possibility of their expansion.

Nowadays temperature characteristics in Ukraine correspond to medium risk of malaria expansion (according to the risk classification of the Ministry of health of the Russian Federation). Temperature prognosis till 2030 shows the possible increase of the risk level to a relatively high, which emphasizes the importance of new adaptation measures related to climate change threat. Key words: malaria, malaria parasite, vector (mosquito g. Anopheles), climate change.

Отримано 10.09.2016 р. 